Teka Kom. Politol. Stos. Międzynar. - OL PAN, 2016, 11/2, 25-45

\title{
ZAGROŻENIA EKOLOGICZNE MORZA ŚRÓDZIEMNEGO WYZWANIEM DLA ROZWOJU SAMOPODTRZYMUJĄCEGO SIE
}

\author{
Katarzyna Stachurska-Szczesiak \\ Zakład Stosunków Międzynarodowych, Wydział Politologii \\ Uniwersytet Marii Curie-Skłodowskiej w Lublinie \\ e-mail: kstachurska9@wp.pl
}

\begin{abstract}
Streszczenie: Środowisko naturalne warunkowało rozwój społeczno-gospodarczy państw nadbrzeżnych Morza Śródziemnego (MŚ), które paradoksalnie ponoszą odpowiedzialność za obecny stan śródziemnomorskiej fauny i flory. Na początku XXI wieku wszystkie badania dotyczące środowiska morskiego Śródziemnomorza były zgodne w kwestii stale pogarszającej się kondycji zdrowotnej Mare Nostrum. Problemy te są coraz bardziej widoczne (w postaci unoszących się śmieci) na południowych wybrzeżach basenu Morza Śródziemnego (BMŚ). Fakt ten był przez wiele lat zaniedbywany przez rozwijające się państwa Południa, które koncentrowały się bardziej na utrzymaniu wzrostu gospodarczego niż zachowaniu i ochronie środowiska naturalnego. W ostatnim czasie, mimo niestabilnej sytuacji w regionie, wzrosła świadomość, że problemy związane ze środowiskiem naturalnym są często przekrojowe i wymagają rozwiązań opartych na współpracy międzynarodowej, tym bardziej jeśli chodzi o wspólną przestrzeń, jaką jest Morze Śródziemne. Kluczowym rozwiązaniem dla utrzymania dobrego stanu środowiska morskiego i rozwoju gospodarczo-społecznego Śródziemnomorza jest wdrażanie zasad koncepcji rozwoju samopodtrzymującego się. Celem artykułu jest analiza działań państw nadbrzeżnych oraz UE w kierunku ochrony Morza Śródziemnego, torujących drogę do ustanowienia rozwoju samopodtrzymującego się w BMŚ w przyszłości.
\end{abstract}

Slowa kluczowe: zagrożenia ekologiczne, Morze Śródziemne, rozwój samopodtrzymujący się, działania UE, współpraca w regionie śródziemnomorskim

\section{WSTĘP}

Rozwój samopodtrzymujący się stał się koncepcją globalną wraz ze Światowym Szczytem Ziemi Narodów Zjednoczonych, który odbył się w Rio de Janeiro w 1992 roku. Następstwem Szczytu było opublikowanie Raportu Światowej Komisji ds. Środowiska i Rozwoju, tzw. Raportu Brundtland, przygotowanego w 1987 roku. Przywoływał on koncepcję rozwoju samopodtrzymującego się (RS), 
stanowiącą jednocześnie kluczową definicję na potrzeby niniejszego artykułu, traktującą „rozwój jako taki, który odpowiadałby potrzebom pokolenia dzisiejszego bez uszczerbku na potrzeby pokoleń następnych"[Commission mondiale sur l'environnement1989]. Odtąd w ogólnej definicji rozwoju zauważa się dwie zasadnicze kwestie. Rozwój ma wymiar nie tylko ekonomiczny, ale także społeczny i środowiskowy. Rozwój może być rozwojem samopodtrzymującym się trwale tylko wówczas, gdy zaistnieje idealna równowaga między potrzebą wzrostu ekonomicznego i koniecznością zachowania równowagi środowiska naturalnego. Druga kwestia, która zaistniała w momencie ukazania się ww. definicji rozwoju, to taka, iż dzisiejsze pokolenie ma moralny obowiązek pozostawienia zasobów społecznych, ekonomicznych i ekologicznych następnym pokoleniom na takim poziomie, co najmniej porównywalnym, z jakiego korzysta pokolenie obecne. Od momentu pojawienia się koncepcji RS debaty prowadzone wokół problemów ekologicznych skutkowały wzrostem świadomości na temat tego, że eksploatowanie zasobów naturalnych oraz skażenie środowiska naturalnego nie mogą trwać w nieskończoność.

Tak pojmowany rozwój stał się wiodącym celem różnorodnych strategii i programów rozwoju na poziomie globalnym, narodowym, regionalnym oraz lokalnym [Baum i Śleszyński 2008]. Przejawy funkcjonowania koncepcji RS są widoczne nie tylko w polityce Narodów Zjednoczonych, lecz także coraz bardziej na poziomie Unii Europejskich. Celem niniejszej publikacji jest analiza zagrożeń ekologicznych w przestrzeni Morza Śródziemnego (MŚ) oraz działań UE, ze szczególnym uwzględnieniem instrumentów na rzecz ochrony środowiska morskiego, które stają się wyzwaniem dla rozwoju samopodtrzymującego się. Analizie poddano dwie hipotezy badawcze. Po pierwsze, wzrost aktywności międzynarodowych podmiotów w basenie Morza Śródziemnego (BMŚ), w tym UE, wzmacnia dotychczasową ochronę środowiska morskiego i przybrzeżnego przed postępującą degradacją, stanowiąc niezbędny element dążenia do ustanowienia RS w przyszłości w tej części świata. Po drugie, ochrona i zachowanie środowiska morskiego i przybrzeżnego dla przyszłych pokoleń wymaga specyficznej współpracy państw nadbrzeżnych MŚ, opartej na podejściu ekosystemowym. Dla uzasadnienia powyższych hipotez zastosowano kilka technik i metod badawczych, tj. analizę stanu literatury, analizę materiałów źródłowych i technik statystycznych oraz metodę porównawczą ilościową.

${ }^{1}$ Istnieje wiele definicji czy odmian koncepcji RS, począwszy od tych, które akcentują komponent środowiskowy, poprzez te, które skupiają się na wymiarze gospodarczym tak pojmowanego rozwoju, po te, które zwracają uwagę przede wszystkim na wymiar społeczny tego rozwoju ze względu na problemy społeczne, tj. ubóstwo, wykluczenie czy bezrobocie, bez ich rozwiązania nie można bowiem realizować w pełni koncepcji rozwoju określonej w Raporcie Brundtland. 


\section{WYZWANIA EKOLOGICZNE W BMŚ}

Bogactwo i różnorodność ludzi i kultur BMŚ, stanowiącego kolebkę wielu cywilizacji, są wynikiem uprzywilejowanej przestrzeni naturalnej. Otóż to właśnie środowisko naturalne warunkowało rozwój społeczno-gospodarczy państw nadbrzeżnych MŚ, które paradoksalnie ponoszą odpowiedzialność za obecny stan śródziemnomorskiej fauny i flory [Hervé 2011]. Można się zastanowić, dlaczego środowisko naturalne w BMŚ jest obecnie bardziej niż kiedykolwiek wyzwaniem, które obejmuje wiele problemów? Odpowiedź na to zasadnicze pytanie można znaleźć już w analizie J. Ponceta z lat 70. XX wieku [Poncet 1973a]. Autor ten twierdzi, że wspólnoty społeczne usytuowane na południu BMŚ nie były w stanie trwale zapanować nad siłami fizycznymi, a tym samym ochraniać swoje środowisko przed ich naturalnymi negatywnymi skutkami. Wymagania, potencjał środowiskowy, klimat, stan biologiczny były również doświadczane czy eksploatowane wraz z rozwojem ludzkości i dostępnych jej technik; pokolenia następowały po sobie i stopniowo zagospodarowywały przestrzeń odpowiednimi sposobami upraw. Z czasem uległy zmianie wszelkie warunki produkcji, co skutkowało wzrostem korzystania ze środowiska naturalnego. Te wszystkie zjawiska wzmacniały się we wzajemnym powiązaniu, co wywołało negatywny wpływ na procesy zmian fizycznych środowiska oraz zmianę zachowań ludzkich. Zarówno pozytywne jak i negatywne skutki tych zachowań mogą bardziej lub mniej zmieniać sam krajobraz ludzkości. Lecz stan środowiska naturalnego, które obserwuje się w BMŚ, to nie tylko prawa naturalne. Każda władza dążyła do rozbudowy, propagowania materialnych zdobyczy, nie martwiąc się o odnowienie lub zachowanie własnego środowiska naturalnego. Niezależnie od okoliczności wcześniejsze społeczeństwa były w stanie odnosić sukcesy, konkurować i walczyć, odnawiać się i niszczyć wzajemnie bądź eksploatować bardziej lub mniej trwale swoją przestrzen, a nawet dokonywać ekspansji kolonialnej nowych terenów, które z kolei mogły stać się nośnikami głównych ośrodków cywilizacji i władzy [Poncet 1973b]. Jednak nawet najpotężniejsze i najlepiej zorganizowane państwa czy społeczeństwa w historii BMŚ, które pozostawiały najwięcej śladów dotyczących ich zdolności do urządzania środowiska naturalnego (nawadnianie, ochrona dorzeczy, usługi sanitarne), nigdy nie poświęciły wystarczająco dużo uwagi odnowie szaty roślinnej czy gruntów, regeneracji zniszczeń czy walce z nadmierną ich eksploatacją.

Współcześnie problemy środowiska śródziemnomorskiego nie są już nie do pokonania. Społeczeństwa BMŚ, głównie w rozwiniętych państwach Północy, pragną żyć w środowisku mniej zdegradowanym i eksploatowanym, z kolei społeczeństwom państw rozwijających się Południa brakuje olbrzymich zasobów zgromadzonych przez naszą cywilizację. Destrukcyjne procesy erozji środowiska naturalnego, wylesienia, susze, nadmierna eksploatacja ziem i zasobów, powodzie nie tylko ulegają przyśpieszeniu, lecz także zyskują inne znaczenie wraz z rosnącą liczbą ludności i procesami jej ubożenia [Poncet 1973a]. W tym kontekście 
koncepcja rozwoju samopodtrzymującego się przynosi odpowiedź na bolączki związane ze stanem środowiska naturalnego w BMŚ, regularnie eksploatowanego przez wcześniejsze cywilizacje.

Aktualne obserwacje naukowe i scenariusze dotyczące przyszłości MŚ są mocno niepokojące. Według nich globalne zmiany klimatyczne lokalnie najbardziej dotkną region śródziemnomorski. Raport Planu Niebieskiego z 2009 roku na temat stanu środowiska i rozwoju w regionie MŚ wskazuje, że w nadchodzących dziesięcioleciach nastąpi wzrost temperatury powietrza w regionie nawet o kilka stopni, przy jednoczesnym spadku opadów i podniesieniu poziomu morza do 35 $\mathrm{cm}$ (chociaż według niektórych danych nawet do $60 \mathrm{~cm}$ ) (Mediterranean Climate Change Adaptation), a także wzrost częstotliwości występowania gwałtownych zjawisk, tj. susz, powodzi [Etat de l'environnement 2009]. Szkody, jakie powstały w wyniku katastrof oraz gwałtownych zmian w długim okresie, są wielorakie: zmiany w obiegu wody, bioróżnorodności, w stanie lasów i gruntów są następstwem wpływu człowieka na środowisko naturalne. Zagrożenia te jednak nie dotknęły w równym stopniu wszystkich mieszkańców (460 mln) Śródziemnomorza.

Ogólnie rzecz ujmując, wiele danych wskazuje na to, iż państwa Południa i Wschodu BMŚ będą bardziej narażone na procesy pustynnienia czy brak wody. Woda okazuje się najważniejszym wyzwaniem w przestrzeni śródziemnomorskiej. Jako centrum życia BMŚ poddawana jest wszelkim sposobom eksploatacji przez człowieka. Ten naturalny zasób niezbędny do życia pozostaje bardzo rzadki w Libii, Syrii, Egipcie, a nawet Izraelu. Wzrost popytu na wodę zwłaszcza w rolnictwie (nawadnianie), nagromadzenie dużej liczby ludzi w centrach miejskich (nadmierna urbanizacja, głównie wzdłuż linii brzegowej MŚ) wzmacniane aktywnością ekonomiczną, generują zanieczyszczenia, które destabilizują równowagę ekosystemów, zarówno samego MŚ, jak i jego wybrzeży [Stachurska-Szczesiak 2015]. Do tego dochodzą nadmierne połowy i intensywne praktyki rolne oraz zjawisko uprzemysłowienia charakterystyczne dla państw rozwijających się. Z kolei turystyka, która dla wielu państw śródziemnomorskich jest główną gałęzią gospodarki, rodzi kolejne wyzwania z tytułu przemieszczania się i nagromadzenia ludzi w czasie i przestrzeni [Weigert 2012]. Powyższe zjawiska łącznie mają wpływ na stan środowiska morskiego Śródziemnomorza. Zrzuty przemysłowe, ścieki komunalne i odpady dryfujące wzdłuż linii brzegowej stanowią zagrożenie dla zdrowia i życia roślin, zwierząt i ludzi. Około 1/3 światowego handlu morskiego przechodzi przez MŚ. Drogi te, oceniane jako najbardziej ruchliwe na świecie, stanowią swoista „bombę”, która może eksplodować na skutek klęsk żywiołowych czy błędu człowieka w postaci wycieków ze statków bądź kontenerowców olbrzymiej ilości ropy naftowej czy niebezpiecznych związków chemicznych, powodując nieodwracalne szkody [Frémont 2008].

W ostatnich latach dokonał się postęp w zakresie instytucjonalizacji środowiska morskiego i współpracy subregionalnej MŚ, zwłaszcza w celu jego ochrony przed zanieczyszczeniami oraz ochrony bioróżnorodności, czego wyrazem są poniższe działania UE oraz środowiska międzynarodowego w BMŚ. 


\section{RADIOSKOPIA (HADHRI 2006) DZIAŁAŃ NA RZECZ OCHRONY ŚRODOWISKA MORSKIEGO BMŚ}

Morze Śródziemne jest złożonym środowiskiem w swoich wymiarach ekologicznych i społecznych. Ramy współpracy wszystkich państw nadbrzeżnych MŚ tworzy Konwencja o ochronie Morza Śródziemnego przed zanieczyszczeniem, zwana Konwencją barcelońską, przyjęta w Barcelonie 16 lutego 1976 roku, zmieniona 10 czerwca 1995 roku (Convention de Barcelone pour la protection). Z biegiem czasu jej mandat został rozszerzony o planowane i zintegrowane zarządzanie obszarami przybrzeżnymi (Convention sur la protection du milieu marin). Konwencja wyznacza cele i wspólne standardy oraz ułatwia wymianę informacji między 22 państwami. Stroną Konwencji jest także UE, która decyzją Rady nr 585 z 1977 roku oraz innymi następnymi decyzjami (zob. tab. 1) przystąpiła do Konwencji barcelońskiej i Protokołu o zapobieganiu zanieczyszczeniom Morza Śródziemnego przez zatapianie odpadów ze statków i samolotów [Décision du Conseil 1977].

Tabela 1. Akty prawne UE dotyczące ochrony środowiska morskiego i regionu przybrzeżnego MŚ (z tytułu uczestnictwa UE w Konwencji barcelońskiej)/ EU legislation on the protection of the Marine Environment and the Coastal Region of the Mediterranean (due to EU participation in the Barcelona Convention)

\begin{tabular}{|c|c|c|}
\hline Podstawa prawna & Wejście w życie & Dziennik Urzędowy WE/ JO \\
\hline Decyzja 77/585/CEE & 25.07 .1977 & JO L 240 z 19.09 .1977 \\
\hline Decyzja 81/420/CEE & 19.05 .1981 & JO L 162 z 19.06 .1981 \\
\hline Decyzja 83/101/CEE & 28.02 .1983 & JO L 67 z 12.03.1989 \\
\hline Decyzja 84/132/CEE & 1.03 .1984 & JO L 68 z 10.03.1984 \\
\hline Decyzja 2004/575/CE & 29.04 .2004 & JO L 261 z 6.08.2004 \\
\hline Decyzja 2010/631/EU & 13.09 .2010 & JO L 279 z 23.10.2010 \\
\hline
\end{tabular}

Źródło: Barcelona Convention for the protection of the Mediterranean.

Naczelnym celem Konwencji jest realizacja rozwoju samopodtrzymującego się w BMŚ. „Strony Konwencji i UE są zdeterminowane, aby stawiać czoła rosnącym wyzwaniom związanym z ochroną środowiska morskiego i wybrzeży MŚ, dynamizując plany rozwoju samopodtrzymującego się zarówno na szczeblu regionalnym jak i narodowym" (Convention de Barcelone pour la protection). Konwencja i jej Protokoły (patrz załącznik nr 1) oraz powstałe strategie mają na celu przede wszystkim poprawę środowiska morskiego BMŚ. Jednak aby to dokonać, należy zwiększyć dostęp do danych na temat stanu, kierunków zmian, zagrożeń dla środowiska MŚ. W tym celu w końcu 2008 roku Strony Konwencji skłoniły Sekretariat do publikowania okresowych sprawozdań na temat stanu środowiska naturalnego MŚ i stref przybrzeżnych. Dyspozycje te miały na celu wzmocnienie monitorowania zmian środowiska naturalnego regionu oraz dokonania oceny pracy Planu działań na rzecz Morza Śródziemnego (Mediter- 
ranean Action Plan for the Barcelona Convention - MAP) ${ }^{2}$, który powstał pod auspicjami Programu Narodów Zjednoczonych ds. Środowiska (United Nations Environment Programme - UNEP). Dane z tej inicjatywy w połączeniu z innymi dostarczyły podstaw do ogólnej oceny środowiska naturalnego w całym BMŚ. Informacje odnoszące się do stanu środowiska i rozwoju w regionie MŚ są przedmiotem systematycznych publikacji, począwszy od roku 2009. Dotyczyły one aktywności i obszarów MAP, które przyczyniły się do podniesienia świadomości o problemach ekologicznych regionu (État du milieu marin et côtier de méditerranée). Od lipca 2008 Strony Konwencji barcelońskiej zobowiązały się także do stopniowego wdrażania podejścia ekosystemowego w zarządzaniu działalnością człowieka w celu poprawy stanu środowiska morza. Podejście to wykracza poza pojedyncze badanie gatunku czy funkcji ekosystemu i rozważa systemy ekologiczne jako złożoną kombinację elementów będących w stałej interakcji (łącząc systemy i ich funkcje). Podejście ekosystemowe to również proces, który stanowi drogowskaz na przyszłość (zob. tab. 2). Wyznacza ono cele i wskaźniki ekologiczne, przyczyniając się także do opracowania definicji „dobrego stanu ekologicznego" dla MŚ. Po raz pierwszy definicja podejścia ekosystemowego została określona w Konwencji dotyczącej różnorodności biologicznej (The Convention on Biological Diversity - CBD) jako „Zintegrowana strategia zarządzania ziemią, wodą i żywymi zasobami, która sprzyja ochronie i trwałemu ich użytkowaniu w sprawiedliwy sposób”(Approche Par Écosystème).

Tabela 2. Warunki dla podejścia ekosystemowego/ Conditions for the ecosystem approach

- Zintegrowane podejście bierze pod uwagę wszystkie elementy ekosystemu (działalność człowieka, gatunki i siedliska, procesy fizyczne)

- Rozpatrzenie funkcji ekosystemu i odpowiednich usług ekosystemów ${ }^{3}$

(Norgaard 2010)

- Znaczny udział interesariuszy; uczestnictwo stron biorących udział

Źródło: Guide de mise en œuvre de l'approche écosystémique, s. 9.

2 W roku 1975, zaledwie trzy lata po Konferencji ministerialnej w Sztokholmie, która stworzyła Program Ochrony Środowiska Narodów Zjednoczonych (UNEP), szesnaście państw śródziemnomorskich oraz Wspólnota Europejska przyjęły Plan Działań na rzecz regionu Morza Śródziemnego (MAP). Był on pierwszym planem, jaki dotychczas przyjęto w ramach Programu mórz regionalnych pod auspicjami UNEP. Dziś MAP obejmuje 21 państw BMŚ i Wspólnoty Europejskiej(WE). Są one wspólnie zobowiązane do stawienia czoła wyzwaniom degradacji środowiska w morzu, obszarów przybrzeżnych i śródlądowych oraz powiązania trwałego i zrównoważonego gospodarowania zasobami w celu ochrony BMŚ i poprawy jakości życia w tym regionie.

3 Usługi ekosystemowi - koncepcja blisko związana z ekonomią ekologiczną i pojęciem kapitału naturalnego. Definiowane są najczęściej jako wkład naturalnych ekosystemów w szeroko pojęty dobrobyt człowieka. Usługi ekosystemowe mogą być interpretowane jako dochód wypływający z kapitału naturalnego. 
Mimo iż znaczenie i wartość linii brzegowej oraz systemów morskich MŚ są dobrze znane (wchłanianie odpadów, łagodzenie burz, utrzymywanie równowagi ekologicznej...), wstępna ocena raportu UNEP/MAP z 2011 roku wskazuje, iż ekosystemy te nadal są degradowane. Wśród głównych sprawców należy wymienić:

- Rozwój gospodarczy - ogólnie pojęty rozwój gospodarczo-społeczny oraz nadmierne osiedlanie się wzdłuż linii brzegowej spowodowane także turystyką i urbanizacją, co prowadzi do zmniejszenia siedlisk wyjątkowych gatunków oraz dalszej erozji gleb;

- Nadmierne połowy - nadmierne połowy oraz przyłów (czyli łapanie w sieci przypadkowych gatunków zwierząt). Jeśli połowy są nadmierne lub prowadzone w nieprawidłowy sposób, to może wywołać negatywny wpływ na środowisko naturalne w postaci zachwiania równowagi ekologicznej morza (wpływ rybołówstwa na środowisko);

- Destrukcyjne rybołówstwo - trałowanie przydenne wyrządza niespotykane szkody siedliskom głębinowym, tzw. bentosom (ośmiornice, gąbki, skorupiaki, glony...itd.);

- Zanieczyszczenie - skażenie ośrodków morskich oraz fauny i flory poprzez zanieczyszczenia w pierwszej kolejności na skutek urbanizacji i przemysłu, ale także przez produkty przeciwporostowe służące do zapewnia ochrony i obsługi technicznej łodzi oraz zrzuty pochodzenia atmosferycznego, składające się z niebezpiecznych związków chemicznych;

- Wzbogacenie się wody w substancje odżywcze - to prowadzi do eutrofizacji i niedotlenienia. Eutrofizacja to wzbogacenie akwenów wodnych w substancje odżywcze (pierwiastki biogenne, głównie azot i fosfor, ale także potas). Normalnie jest to proces powolny, lecz na skutek aktywności człowieka (tj. zrzutów ścieków przemysłowych i komunalnych oraz intensywnego rolnictwa) został na nowo przyspieszony, co często prowadzi do zakłócenia równowagi ekologicznej;

- Zakłócenia spowodowane zanieczyszczeniami - jest to związane z (rutynowym bądź na skutek katastrof) przepływem morskim, łącznie z transportem morskim, energią, akwakulturą i odsalaniem;

- Rozprzestrzenianie się drapieżnych gatunków - wzrost gatunków drapieżnych jest wynikiem często zmian klimatycznych;

- Degradacja stref przejściowych i ujść rzek - negatywny wpływ zarówno dla rybołówstwa handlowego, jak i miejsc, w których żyją unikalne gatunki [opracowanie własne na podstawie État du milieu marin et côtier 2012 4a]. Mimo iż zgodnie ze wspomnianym raportem jakość wody w BMŚ znacznie się polepszyła, a poziom substancji niebezpiecznych typu DDT i metali ciężkich obniżył się, to pojawiły się nowe problemy związane z odsalaniem i jego następstwami; akwakulturą, zwłaszcza z uwagi na instalowanie urządzeń do tuczenia tuńczyka błękitnopłetwego oraz pojawieniem się tzw. skumulowanego ryzyka związanego z niedoborem dostępu do swobodnego wolnego miejsca i konkurencyjnych zastosowań [État du milieu marin et côtier 2012 5a]. Nowe problemy 
związane są także z nadal niewystarczającą wiedzą na temat czynników wpływających na zmiany w ekosystemach. Mimo silnego trendu odzwierciedlającego wzrost zainteresowania tematyką ekologiczną i wpływem działalności człowieka na środowisko naturalne, często są one skupione na obszarach strefy przybrzeżnej, kosztem innych środowisk. Jako reakcję na opublikowanie opinii o stanie morza z 2011 roku strony Konwencji barcelońskiej rozwinęły serię celów oraz wskaźników ekologicznych i operacyjnych (zob. tab. 3), które wyznaczają priorytety w BMŚ. Proces ten ma na celu określenie zintegrowanej i adaptacyjnej strategii morskiej pozwalającej na zastosowanie wspomnianego podejścia ekosystemowego w BMŚ oraz na osiągnięcie określonych celów ekologicznych.

Tabela 3. Zintegrowane cele ekologiczne dla środowiska morskiego i przybrzeżnego MŚ opracowane przez PNUE/MAP/ Integrated environmental goals for the marine and coastal environment of the Mediterranean developed by PNUE / MAP

\begin{tabular}{|l|l|}
\hline \multicolumn{1}{|c|}{ Cele } & \multicolumn{1}{|c|}{ Skutek } \\
\hline Zachowanie różnorodności biologicznej & $\begin{array}{l}\text { Co oznaczałoby jakość i występowanie siedlisk przy- } \\
\text { brzeżnych i morskich gatunków oraz ich odpowied- } \\
\text { nie rozmieszczenie }\end{array}$ \\
\hline Kontrola obcych gatunków & $\begin{array}{l}\text { Utrzymywanie obcych gatunków wprowadzonych } \\
\text { przez działalność człowieka na takich poziomach, } \\
\text { aby nie wywierały one negatywnych skutków na eko- } \\
\text { systemy }\end{array}$ \\
\hline $\begin{array}{l}\text { Kontrola populacji niektórych gatunków } \\
\text { ryb/skorupiaków eksploatowanych w ce- } \\
\text { lach handlowych }\end{array}$ & $\begin{array}{l}\text { Utrzymywanie ich w bezpiecznych granicach biolo- } \\
\text { gicznych }\end{array}$ \\
\hline Zmiany morskiego łańcucha pokarmowego & $\begin{array}{l}\text { Wywołana przez działalność człowieka nie powinna } \\
\text { powodować szkodliwego wpływu w dłuższej per- } \\
\text { spektywie czasu }\end{array}$ \\
\hline Unikanie eutrofizacji & $\begin{array}{l}\text { Zwłaszcza szkodliwych jej skutków, które pociągają } \\
\text { za sobą utratę bioróżnorodności, degradację ekosys- } \\
\text { temów, proliferację szkodliwych glonów, niedobór } \\
\text { tlenu w dolnych partiach wód }\end{array}$ \\
\hline Zachowanie integralności dna morskiego & Zwłaszcza w priorytetowych siedliskach dennych \\
\hline Modyfikacje warunków hydrograficznych & $\begin{array}{l}\text { Nie wywołują niekorzystnego wpływu na ekosyste- } \\
\text { my morskie }\end{array}$ \\
\hline Zachowanie naturalnej dynamiki obszarów przybrzeżnych, ekosystemów i krajobrazów \\
\hline $\begin{array}{l}\text { Zanieczyszczenia nie mają znaczącego wpływu na ekosystemy morskie i przybrzeżne oraz zdrowie } \\
\text { ludzkie }\end{array}$ \\
\hline Odpady morskie i przybrzeżne nie mają negatywnego wpływu na środowisko morskie i przybrzeżne \\
\hline Hałas generowany przez działalność człowieka nie powoduje znaczącego wpływu na ekosystemy \\
\hline
\end{tabular}

Źródło: État du milieu marin et côtier, s. 7.

Powyższe cele posłużyły za solidny fundament do przyszłych raportów na temat stanu środowiska morskiego i przybrzeżnego MŚ. Zintegrowana ocena prowadzona pod auspicjami UNEP/MAP, wraz z uczestnikami, tj. MEDPOL (Med Pol programme), RAC/SPA(RAC/SPA Regional Activity) i BP/RAC (BP/ 
RAC Blue Plan), skutkowała kolejnymi raportami regionalnymi i lokalnymi na temat stanu środowiska morskiego. Zatem wartością dodaną raportu z 2011 roku jest opracowanie narodowych raportów na temat stanu środowiska morskiego, z uwzględnieniem specyficznych cech MŚ. Raport miał następujące cele:

- określenie aktualnego obrazu czynników, presji i stanu środowiska morskiego i przybrzeżnego MŚ, z położeniem akcentu na ostatnie zmiany $\mathrm{w}$ warunkach środowiskowych i z dokonaniem przeglądu wpływu działalności człowieka;

- zwrócenie uwagi na najtrudniejsze i najbardziej palące kwestie regionalne, określone zarówno przez państwa śródziemnomorskie, jak i przez UNEP/ MAP;

- sporządzenie „mapy drogowej” do dalszej realizacji podejścia ekosystemowego (Application de l'approche écosystémique) w zarządzaniu aktywnością ludzką, która może obciążać środowisko śródziemnomorskie zarówno na poziomie narodowym, jak i regionalnym czy globalnym (État du milieu marin et côtier).

Następstwem raportu było zwrócenie uwagi na skutki środowiskowe społeczno-gospodarczej aktywności człowieka oraz skuteczna reakcja na presję z tym związaną. Zastosowanie mechanizmów monitorujących podejście ekosystemowe i raportów na temat stanu środowiska morskiego i przybrzeżnego stanowią dwie fazy tego samego procesu, które wzmacniają się wzajemnie.

Wyżej wspomniane cele środowiskowe są zbieżne z dyrektywą ramową UE pt. Strategia na rzecz środowiska morskiego UE z 17 czerwca 2008 roku [Directive 2008/56/CE]. W art. 3. dyrektywy czytamy: „Środowisko morskie jest cennym dziedzictwem, które należy chronić, zachować oraz, w miarę możliwości, odnawiać w sposób pozwalający w ostatecznym rozrachunku na utrzymanie różnorodności biologicznej oraz zachowanie zróżnicowanego i dynamicznego charakteru oceanów i mórz, które są czyste, zdrowe i urodzajne. W tym względzie niniejsza dyrektywa powinna m.in. promować włączenie kwestii środowiskowych do wszystkich właściwych dziedzin polityki oraz stanowić filar dotyczący środowiska w przyszłej polityce morskiej Unii Europejskiej" [Directive 2008/56/CE]. Strategia ta jest zgodna z decyzją PE i Rady z 22 lipca 2002 roku ustanawiającą Szósty Wspólnotowy program działań w zakresie środowiska naturalnego [Décision 1600/2002/CE]. Ma ona na celu wspieranie trwałego i samopodtrzymującego się użytkowania mórz oraz zachowania ekosystemów morskich. W art. 4 Strategii w pkt C MŚ zostało wymienione jako integralna część podlegająca suwerenności bądź jurysdykcji państw członkowskich UE. Widnieje także wyraźny zapis o tym, iż do 15 lipca 2012 roku państwa członkowskie dokonają wstępnej oceny stanu środowiska danych wód oraz określą cele środowiskowe i związane z nimi wskaźniki, zaś do 15 lipca 2014 roku państwa te opracują i wdrożą program monitorowania dla bieżącej oceny oraz regularnego uaktualniania celów [Directive 2008/56/ CE]. Dyrektywa ramowa ustanawiająca Strategię morską dostarczyła również wytycznych dotyczących ochrony środowiska dla dyrektywy nr 89 dotyczącej 
planowania przestrzennego obszarów morskich ${ }^{4}$ z 23 lipca 2014 roku [Dyrektywa Parlamentu Europejskiego i Rady 2014/89/UE]. Artykuł 1 dyrektywy 89 wyraźnie oddaje istotę oraz przyczyny jej powstania jako przejawu konieczności zastosowania zintegrowanego podejścia w zakresie planowania i zarzadzania. „Wysoki i szybko rosnący popyt na przestrzeń morską do wykorzystania w różnych celach, takich jak instalacje w celu wytwarzania energii ze źródeł odnawialnych, poszukiwanie i eksploatacja ropy naftowej i gazu, transport morski i działalność połowowa, ochrona ekosystemu i różnorodności biologicznej, wydobycie surowców, turystyka, urządzenia akwakultury i podwodne dziedzictwo kulturowe, jak również występowanie licznych presji na zasoby przybrzeżne, wymagają zintegrowanego podejścia w zakresie planowania i zarządzania" [Dyrektywa Parlamentu Europejskiego i Rady 2014/89/UE]. Podejście to zostało przedstawione w Zintegrowanej polityce morskiej (ZPM UE), obejmującej - jako filar środowiskowy - wspomnianą dyrektywę ramową z 2008 roku. Celem ZPM jest wspieranie rozwoju samopodtrzymującego się mórz i oceanów oraz rozwijanie skoordynowanego, spójnego i przejrzystego procesu decyzyjnego w odniesieniu do polityk sektorowych UE dotyczących mórz i oceanów, obszarów przybrzeżnych, wysp i regionów najbardziej oddalonych oraz sektorów morskich, w tym poprzez strategie dotyczące basenów morskich lub strategie makroregionalne, a jednocześnie zapewnienie dobrego stanu środowiska zgodnie z dyrektywą ramową. Planowanie przestrzenne obszarów morskich wspiera i ułatwia realizację strategii „Europa 2020” [Komunikat Komisji Europa 2020], przyjętej przez Radę Europejską w konkluzjach z 17 czerwca 2010 roku. U podstaw strategii „Europa 2020", kreującej wizję Europy roku 2020, leżą trzy priorytety, wśród których, obok rozwoju inteligentnego i sprzyjającego włączeniu społecznemu, leży rozwój samopodtrzymujący się, oznaczający wspieranie gospodarki efektywnej, korzystającej z zasobów, bardziej przyjaznej środowisku naturalnemu i bardziej konkurencyjnej (Komunikat Komisji Europa 2020). Priorytety te są wzajemnie powiązane i dają obraz europejskiej społecznej gospodarki rynkowej XXI wieku. Przybrzeżne i morskie sektory dysponują znacznym potencjałem $\mathrm{w}$ dziedzinie rozwoju samopodtrzymującego się i mają kluczowe znaczenie we wdrażaniu strategii „Europa 2020” [Dyrektywa Parlamentu Europejskiego i Rady 2014/89/ UE]. Powstaje pytanie: Dlaczego UE potrzebuje regulacji dotyczących planowania przestrzennego obszarów morskich oraz jakie korzyści wynikają z ich planowania przestrzennego? Otóż konkurowanie o przestrzeń morską (w sytuacjach wymienionych w art. 1 dyrektywy 89) pociąga za sobą konieczność skutecznego zarządzania, aby zapobiec konfliktom i umożliwić współpracę między sektorami (Morskie planowanie przestrzenne). Z planowania przestrzennego obszarów morskich wynikają m.in. następujące korzyści:

4 Morskie planowanie przestrzenne to planowanie dotyczące tego, gdzie i kiedy może realizować się działalność ludzka na morzu - tak aby była skuteczna i zrównoważona pod względem ochrony środowiska. 
- mniejsza liczba konfliktów między sektorami i więcej możliwości współdziałania;

- przewidywalność, przejrzystość i jasne zasady sprzyjają inwestycjom, a te z kolei umożliwiają dalsze prace nad wykorzystaniem źródeł energii odnawialnej i rozwojem sieci, tworzenie morskich obszarów chronionych oraz wydobywanie ropy naftowej i gazu ziemnego;

- lepsza koordynacja działań administracji poszczególnych państw dzięki wykorzystaniu jednego wspólnego instrumentu, który pomaga równoważyć rozwój różnych rodzajów działalności morskiej; jest to rozwiązanie prostsze i tańsze;

- intensywniejsza współpraca międzynarodowa między państwami UE dotycząca okablowania, rurociągów, szlaków żeglugowych, instalacji do wytwarzania energii wiatrowej itp.;

- ochrona środowiska poprzez wczesne identyfikowanie wpływu różnorodnego wykorzystania przestrzeni oraz pojawiających się szans [Morskie planowanie przestrzenne].

W komunikacie zatytułowanym „Niebieski wzrost” z 13 września 2012 roku, ukazującym szanse dla trwałego i samopodtrzymującego się wzrostu w sektorach morskich, Komisja wskazała liczne inicjatywy realizowane przez Unię, które służą wdrażaniu strategii „Europa 2020”, oraz szereg działań, na których inicjatywy „Niebieskiego wzrostu” mogłyby się koncentrować w przyszłości i które można odpowiednio wspierać poprzez zwiększenie zaufania inwestorów oraz zagwarantowanie im większej pewności za pośrednictwem planowania przestrzennego obszarów morskich [Communication...La croissance bleue]. „Niebieski wzrost” to dhugoterminowa strategia wspierania trwałego wzrostu w całym sektorze morskim. Zwrócono w niej uwagę na fakt, że morza i oceany stanowią siłę napędową gospodarki europejskiej oraz mają duży potencjał w zakresie innowacji i wzrostu. Strategia owa pomaga realizować w ramach ZPM UE cele strategii „Europa 2020”. Według danych „niebieska” gospodarka generuje 5,4 mln miejsc pracy oraz wartość dodaną brutto, sięgającą prawie 500 mld euro rocznie (Blue Growth). Strategia składa się z trzech części:

1. Środki szczególne dotyczące ZPM

- szerzenie wiedzy o morzu, aby poprawić dostęp do informacji o morzu;

- morskie planowanie przestrzenne, aby zapewnić skuteczne i trwałe zarządzanie działaniami na morzu;

- zintegrowany nadzór morski, aby właściwe organy miały wyraźniejszy obraz sytuacji na morzu.

2. Strategie dotyczące konkretnych basenów morskich, mające na celu zapewnienie odpowiednich środków na rzecz promowania trwałego i zrównoważonego wzrostu, przy uwzględnieniu czynników lokalnych, klimatycznych, oceanograficznych, gospodarczych, kulturowych i społecznych (zob. tab. 4). 
Tabela 4. Strategie UE na rzecz basenów morskich

\begin{tabular}{|l|c|c|}
\hline \multicolumn{1}{|c|}{ Nazwa morza bądź oceanu } & Dokument & Data \\
\hline Morze Adriatyckie z Morzem Jońskim & COM (2014) 357 & 17.06 .2014 \\
\hline Ocean Arktyczny & JOIN (2016) 21 & 27.04 .2016 \\
\hline Ocean Atlantycki & COM (2013) 279 & 13.05 .2013 \\
\hline Morze Bałtyckie & SWD (2014) 167 & 16.05 .2014 \\
\hline Morze Czarne & SWD (2015) 6 & 20.01 .2015 \\
\hline \multirow{2}{*}{ Morze Śródziemne } & COM (2012) 713 & 30.11 .2012 \\
& COM (2014) 357 & 17.06 .2014 \\
\hline \multirow{2}{*}{ Morze Północne } & Materiał roboczy dotyczący strategii Morza \\
& \multicolumn{2}{|c|}{ Północnego; Haga 20-21 czerwca 2016 } \\
\hline
\end{tabular}

Źródło: Opracowanie własne.

3. Ukierunkowane podejście w niektórych dziedzinach:

- akwakultura;

- turystyka nadmorska;

- biotechnologia morska;

- energia oceanu;

- wydobycie z dna morskiego (Blue Growth).

Wyżej wspomniane instrumenty tworzące ZPM UE mają na celu zapewnienie bardziej spójnego podejścia do kwestii morskich oraz większej koordynacji między różnymi obszarami polityki. Koncentrują się one na kwestiach, które:

- nie mieszczą się w ramach jednego obszaru polityki, np. „niebieski wzrost" (wzrost gospodarczy oparty na różnych sektorach gospodarki morskiej);

- wymagają koordynacji między różnymi sektorami i podmiotami (np. popularyzowanie wiedzy o morzu).

Celem ZPM nie jest zastąpienie działań w określonych sektorach gospodarki morskiej, lecz ich koordynacja. Ponadto jest ona potrzebna, aby uwzględnić powiązanie przemysłu i działalności człowieka na morzu. Decyzja podjęta w jednej dziedzinie (niezależnie od tego, czy chodzi o transport morski, porty, energię wiatru, badania morskie, rybołówstwo czy turystykę) może mieć wpływ na wszystkie pozostałe dziedziny, np. budowa morskiej farmy wiatrowej może zakłócić transport, co z kolei może wpłynąć na funkcjonowanie portów. Pomaga zaoszczędzić czas i pieniądze poprzez zachęcanie władz do współdzielenia danych w różnych dziedzinach polityki oraz do wspólnej pracy nad różnymi aspektami tego samego problemu. Pomaga zacieśnić współpracę między osobami odpowiedzialnymi za podejmowanie decyzji w różnych sektorach na wszystkich szczeblach - krajowych, regionalnych i lokalnych władz morskich oraz organów międzynarodowych, zarówno w Europie, jak i poza jej granicami. Wiele państw dostrzega tę potrzebę i dąży do bardziej uporządkowanej i systematycznej współpracy [Integrated maritime policy].

Uzupełnieniem powyższych działań na rzecz ochrony morza jest Śródziemnomorska Strategia na rzecz Rozwoju Samopodtrzymującego się (Mediterranean 
Strategy for Sustainable Development - MSSD) na lata 2016-2025. Strategia ta jest owocem 19. spotkania Konferencji NZ ds. Zmian Klimatu, które odbyło się w Atenach 9-12 lutego 2016 roku i podczas którego Strony Konwencji barcelońskiej przyjęły nową MSSD. Pierwsza Strategia Morza Śródziemnego na rzecz Rozwoju Samopodtrzymującego się na lata 2005-2015 została przyjęta przez Umawiające się Strony Konwencji w Barcelonie w 2005 roku, na 14. posiedzeniu w Portoroz, w Słowenii. Jednak globalny i regionalny kontekst uległ znaczącej zmianie i sprawił, że zaistniała konieczność uwzględnienia nowych instrumentów i podejść adekwatnych do nowych wyzwań w regionie. Mottem naczelnym nowej Strategii jest "inwestować w środowisko naturalne, aby osiągnąć rozwój społeczno-gospodarczy" (Stratégie Méditerranéenne pour le développement durable 2016-2025). Strategia wyznacza ramy polityczne oraz strategiczne wytyczne dla stron Konwencji barcelońskiej. Jest wynikiem procesu integracyjnego z udziałem wszystkich państw członkowskich i kluczowych interesariuszy w regionie. Do głównych zadań Strategii należą: 1) dostarczenie strategicznych ram politycznych, aby w przyszłości ustanowić rozwój samopodtrzymujący się w regionie MŚ; 2) zaadoptować międzynarodowe zobowiązania do warunków regionalnych, poprowadzić strategie narodowe i stymulować współpracę regionalną do realizacji celów RS; 3 ) połączyć konieczność ochrony środowiska naturalnego z rozwojem społeczno-gospodaczym. Strategia nawiązuje do wyników Konferencji NZ w sprawie Rozwoju Samopodtrzymującego się (Rio+20), która położyła szczególny nacisk na zielony wzrost w kontekście rozwoju samopodtrzymującego się i wykorzenienie ubóstwa (Konferencja Narodów Zjednoczonych w sprawie Zrównoważonego Rozwoju). MSSD 20162025 ma na celu przyczynić się w sposób znaczący w długiej perspektywie czasu do ustanowienia rozwoju samopodtrzymującego się w regionie MŚ, zwłaszcza w kontekście Agendy 2030 na temat Rozwoju Samopodtrzymującego się (Agenda 2030 for Sustainable Developement) i Celów Rozwoju Samopodtrzymującego się (Sustainable Developement Goals - SDGs), przyjętych przez Zgromadzenie Ogólne NZ we wrześniu 2015 roku w Nowym Jorku. Nowa MSSD opiera się na zasadzie, że rozwój społeczno-gospodarczy musi być zharmonizowany ze środowiskiem naturalnym i ochroną zasobów naturalnych. Strategia zwraca uwagę na bogate walory przyrodnicze i cywilizacyjne regionu MŚ, jednocześnie uwypukla presję, jakiej MŚ jest poddawane. Dlatego misją MSSD jest odpowiedzieć na te problemy, wskazując konkretny kierunek rozwoju regionu MŚ, którego mieszkańcy cieszą się z wysokiej jakości życia, a RS zapisuje się w granicach odnawialności ekosystemów (Stratégie Méditerranéenne pour le développement durable 2016-2025). Strategia odnosi się do kluczowych sektorów dotkniętych aktywnością człowieka w środowisku morskim i przybrzeżnym poprzez podejście i narzędzia planowania oparte na ekosystemach, tj. zintegrowane zarządzanie strefą przybrzeżną (Integrated Coastal Zone Management - ICZM) (La gestion intégrée des activités), osiedli miejskich i wiejskich czy systemów wiejskich lub rolnych. Kładzie ona jednocześnie akcent na zmiany klimatyczne, które, jak wcześniej wskazano, mogą poważnie wpłynąć na stan środowiska naturalnego regionu, w tym morskiego. Koncentruje się na kwe- 
stiach przekrojowych, które mieszczą się na styku środowiska i rozwoju [Stratégie Méditerranéenne pour le développement durable 2016-2025] (zob. tab. 5).

Tabela 5. Cele nowej MSSD 2016-2025/Goals of the New MSSD 2016-2025

\begin{tabular}{|l|l|}
\hline \multicolumn{2}{|c|}{ CELE MSSD 2016-2025 } \\
\hline 1. & $\begin{array}{l}\text { Zapewnienie rozwoju samopodtrzymującego się obszarów morskich i przybrzeżnych } \\
\text { (morza i wybrzeża) }\end{array}$ \\
\hline 2. & $\begin{array}{l}\text { Wspieranie zarządzania zasobami, produkcją żywności i bezpieczeństwa poprzez } \\
\text { zrównoważone formy rozwoju obszarów wiejskich (zasoby naturalne, wiejskie, rozwój } \\
\text { i żywność) }\end{array}$ \\
\hline 3. & $\begin{array}{l}\text { Zrównoważone planowanie i zarządzanie śródziemnomorskimi miastami } \\
\text { (samopodtrzymujące się miasta, w tym ICZM) }\end{array}$ \\
\hline 4. & Uczynienie kwestii zmian klimatycznych tematem priorytetowym w regionie MŚ (klimat) \\
\hline 5. & $\begin{array}{l}\text { Przejócie do zielonej i niebieskiej gospodarki; (zielona gospodarka włącznie ze } \\
\text { zrównoważoną konsumpcją i produkcją (sustainable consuption and production - SCP) }\end{array}$ \\
\hline 6. & Zarządzanie wspierające rozwój samopodtrzymujący się (zarządzanie) \\
\hline
\end{tabular}

Źródło: Stratégie méditerranéenne pour le développement durable (SMDD 2016-2025).

Wśród wskazanych celów pierwsze miejsce zajmuje zapewnienie rozwoju samopodtrzymującego się w strefach morskich i przybrzeżnych. Cele te odpowiadają Celom Rozwoju Samopodtrzymującego się (Sustainable Development Goals - SDGs) przyjętym we wrześniu 2015 roku przez Organizację Narodów Zjedno-

Tabela 6. Połączenia między celami MSSD a SDGs (porównanie celów odnoszących się do stref morskich i przybrzeżnych)/ Connections between the goals of MSSD and SDGs (comparison purposes relating to the marine and coastal zones

\begin{tabular}{|c|c|c|c|}
\hline $\begin{array}{l}\text { Cele MSSD } \\
2016-2025\end{array}$ & Cele SDGs & $\begin{array}{c}\text { Lista problemów odnoszących } \\
\text { się do celu } 1\end{array}$ & $\begin{array}{l}\text { Seria wytycznych } \\
\text { dla celu } 1\end{array}$ \\
\hline $\begin{array}{l}\text { Cel. 1. Zapew- } \\
\text { nić RS w stre- } \\
\text { fach morskich } \\
\text { i przybrzeżnych }\end{array}$ & $\begin{array}{l}\text { 14. Zachować i eks- } \\
\text { ploatować w sposób } \\
\text { trwały oceany, morza } \\
\text { i zasoby morskie dla } \\
\text { rozwoju samopod- } \\
\text { trzymującego się }\end{array}$ & $\begin{array}{l}\text { Degradacja środowiska natural- } \\
\text { nego oraz zwiększone ryzyko } \\
\text { pochodzące od zanieczyszczeń } \\
\text { i hałasu żeglugi } \\
\text { Utrata różnorodności biologicznej } \\
\text { Fragmentacja i degradacja eko- } \\
\text { systemu } \\
\text { Eksploatacja nietrwałych zasobów } \\
\text { żywych i gatunków egzotycznych } \\
\text { w systemach ekologicznych } \\
\text { Eksploatacja zasobów morskich } \\
\text { nieożywionych } \\
\text { Przyłów gatunków zagrożonych } \\
\text { Wzrost urbanizacji wzdłuż linii } \\
\text { brzegowej wynikający z niewła- } \\
\text { ściwego gospodarowania grun- } \\
\text { tami, nieograniczonego rozwoju } \\
\text { turystyki itp. }\end{array}$ & $\begin{array}{l}\text { 1.1. Wzmocnione } \\
\text { wdrażanie i przestrze- } \\
\text { ganie Protokołów } \\
\text { Konwencji barceloń- } \\
\text { skiej i innych inicjatyw } \\
\text { oraz instrumentów re- } \\
\text { gionalnej polityki uzu- } \\
\text { pełnione podejściem } \\
\text { narodowym } \\
\text { 1.2. Stworzenie i wdro- } \\
\text { żenie mechanizmów } \\
\text { regulacyjnych, w tym } \\
\text { planowanie przestrzeni } \\
\text { morskiej w celu zapo- } \\
\text { biegania i kontroli eks- } \\
\text { ploatacji nietrwałych } \\
\text { zasobów oceanicznych } \\
\text { (Parrain C. 2012) }\end{array}$ \\
\hline
\end{tabular}

Źródło: Opracowanie własne na podstawie/author based on: Stratégie Méditerranéenne pour le développement durable 2016-2025, s. 21-26. 
czonych. Zatem, ze względu na charakter przekrojowy celów, prawie wszystkie SDGs są pośrednio związane z celami nowej MSSD (zob. tab. 6).

Biorąc powyższe pod uwagę, należy stwierdzić, że Strategia dla obszarów morskich i przybrzeżnych opiera się na wzmocnieniu wdrażania i przestrzegania protokołów Konwencji barcelońskiej i innych inicjatyw regionalnych uzupełnionych polityką narodową. Ma ona zasadnicze znaczenie dla MŚ ze względu na fakt, iż MŚ jest niemal zamkniętym morzem, gdzie wymiana wody jest ograniczona na skutek niewielkiego przejścia do oceanu, co sprawia, że jest niezwykle wrażliwe na zanieczyszczenia. Z jednej strony MŚ jest domem dla ogromnej różnorodności ekosystemów i gatunków, z drugiej zaś jest przedmiotem ustawicznej stale rosnącej presji. Problemy związane ze środowiskiem są często przekrojowe i wymagają zatem rozwiązań umocowanych na współpracy międzynarodowej. W warunkach wspólnego akwenu, jakim jest MŚ, współpraca jest niezbędna, ponieważ, jak przywołuje Raport Brundtland, ,,skala naszych interwencji w przyrodzie jest taka, że konkretne skutki naszych decyzji przekraczają granice narodowe" (Commission Mondiale sur l'Environnement).

\section{PODSUMOWANIE}

Morze Śródziemne niemal od zawsze przyciągało cywilizacje. Cierpiał na tym stan jego środowiska ze względu na swe właściwości fizyczne i humanizację. Główne problemy ekologiczne BMŚ są mniej lub bardziej znane i nadal ewoluują (co wskazano w tekście). Wynikają z zaniechania lub braku ciągłości w czasie i przestrzeni praktyki ochronnej. Idąc za J. Poncetem, należy podkreślić, iż „powinny być karalne irytująco zmieniające się stosunki gospodarczo-społeczne i polityczne we wszystkich wspólnotach geograficznych i historycznych Morza Śródziemnego, zwłaszcza od końca średniowiecza" [Poncet J.,1973a] Znaczące różnice w poziomie rozwoju i poziomie życia między państwami, jak również konflikty, które mają negatywny wpływ na inwestycje i rozwój stanowią dodatkowe wyzwania dla rozwoju samopodtrzymującego się w BMŚ w przyszłości. W obliczu wspomnianych zagrożeń państwa śródziemnomorskie pokazują poprzez budowę instrumentów i wzajemną współpracę, że to nie jest jedynie walka z zanieczyszczeniem powietrza, wody czy samego MŚ, lecz działania kompleksowe $\mathrm{i}$ wielopoziomowe. Tym samym walka z zagrożeniami ekologicznymi w regionie śródziemnomorskim nie powinna jedynie ograniczać się do najważniejszych aspektów problemu niszczenia środowiska naturalnego, w tym morskiego, lecz winna dotyczyć także prawdziwych wymiarów ryzyka i ewolucyjnego ich tła. W tym celu państwa BMŚ powinny skoncentrować się na precyzyjnym zbieraniu i analizowaniu danych dotyczących stanu środowiska naturalnego. Dążenie do postępu i zbiorowego przeżycia wiąże się z radykalną zmianą kursu i sposobu myślenia. Wymaga to szczególnego rozwoju, takiego, jak określa to koncepcja RS, który pozwala na ogólną racjonalizację działań zbiorowych, aby ochraniać 
i przywrócić środowisko naturalne do jego granic odnawialności. Nadzieję w tym względzie przynosi nowa Śródziemnomorska Strategia na rzecz Rozwoju Samopodtrzymującego się przygotowana na lata 2016-2025.

Załacznik 1. Podpisanie i ratyfikowanie Konwencji barcelońskiej i jej Protokołów. Stan na dzień 31 lipca 2015/ The signing and ratification of the Barcelona Convention and its Protocols. As at July 31,2015

\begin{tabular}{|l|l|l|c|c|}
\hline \multirow{2}{*}{ Strony Konwencji } & \multicolumn{4}{|c|}{ 1976 rok Konwenc barcelońska - 1/ } \\
\cline { 2 - 5 } & Podpisanie & \multicolumn{1}{|c|}{ Ratyfikacja } & $\begin{array}{c}\text { Akceptacja zmian } \\
\text { z 1995 roku }\end{array}$ & $\begin{array}{c}\text { Wejście } \\
\text { w życie }\end{array}$ \\
\hline 1. Albania & & $30.05 .90 / \mathrm{AC}$ & 26.07 .01 & 09.07 .04 \\
\hline 2. Algieria & & $16.02 .81 / \mathrm{AC}$ & $09.06-04$ & 09.07 .04 \\
\hline 3. Bośnia i Hercegowina & & $22.10 .94(\mathrm{SUC})$ & - & - \\
\hline 4. Chorwacja & & $12.06 .92(\mathrm{SUC})$ & 03.05 .99 & 09.07 .04 \\
\hline 5. Cypr & 16.02 .76 & 19.11 .79 & 18.07 .03 & 09.07 .04 \\
\hline 6. Unia Europejska & 13.09 .76 & $16.03 .78 / \mathrm{AP}$ & 12.11 .99 & 09.07 .04 \\
\hline 7. Egipt & 16.02 .76 & $24.08 .78 / \mathrm{AP}$ & 11.02 .00 & 09.07 .04 \\
\hline 8. Francja & 16.02 .76 & $11.03 .78 / \mathrm{AP}$ & 29.03 .01 & 09.07 .04 \\
\hline 9. Grecja & 16.02 .76 & 03.01 .79 & 10.03 .03 & 09.07 .04 \\
\hline 10. Izrael & 16.02 .76 & 03.03 .78 & 29.09 .05 & 29.10 .05 \\
\hline 11. Włochy & 16.02 .76 & 03.02 .79 & 07.09 .99 & 09.07 .04 \\
\hline 12. Liban & - & $08.11 .77 / \mathrm{AC}$ & & $*$ \\
\hline 13. Libia & 31.01 .77 & 31.01 .79 & 12.01 .09 & 11.02 .09 \\
\hline 14. Malta & 16.02 .76 & 30.12 .77 & 28.10 .99 & 09.07 .04 \\
\hline 15. Monako & 16.02 .76 & 20.09 .77 & 11.04 .97 & 09.07 .04 \\
\hline 16. Czarnogóra & - & 19.11 .07 & 19.11 .07 & 19.12 .07 \\
\hline 17. Maroko & 16.02 .76 & 15.01 .80 & 07.12 .04 & 06.01 .05 \\
\hline 18. Słowenia & - & $16.09 .93 / \mathrm{AC}$ & 08.01 .03 & 09.07 .04 \\
\hline 19. Hiszpania & 16.02 .76 & 17.12 .76 & 17.02 .99 & 09.07 .04 \\
\hline 20. Syria & - & $26.12 .78 / \mathrm{AC}$ & 10.10 .03 & 09.07 .04 \\
\hline 21. Tunezja & 25.05 .76 & 30.07 .77 & 01.06 .98 & 09.07 .04 \\
\hline 22. Turcja & 16.02 .76 & 06.04 .81 & 18.09 .02 & 09.07 .04 \\
\hline
\end{tabular}

Przystąpienie $($ Accession $=$ AC) Zatwierdzenie $($ Approval $=$ AP) Sukcesja $($ Succession $=$ SUC $)$ 


\begin{tabular}{|c|c|c|c|c|c|c|}
\hline 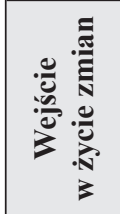 & 1 & 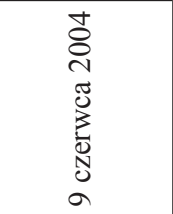 & 1 & 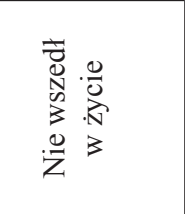 & 1 & 1 \\
\hline 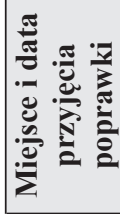 & 1 & 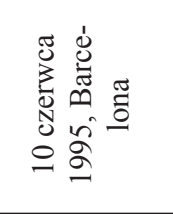 & 1 & 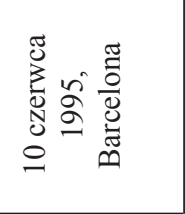 & 1 & 1 \\
\hline 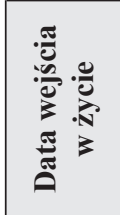 & 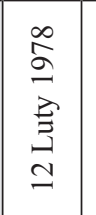 & 1 & 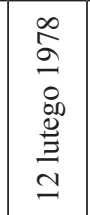 & 1 & 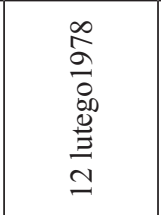 & 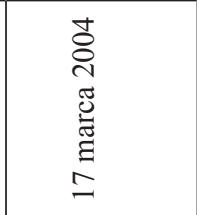 \\
\hline 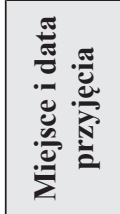 & 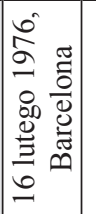 & 1 & 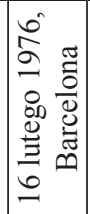 & 1 & 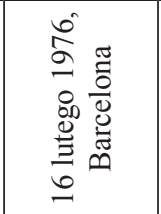 & 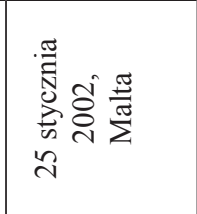 \\
\hline 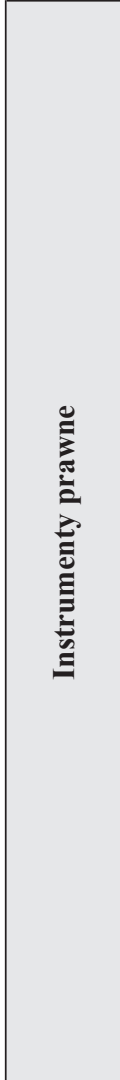 & 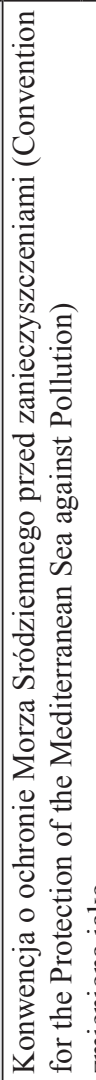 & 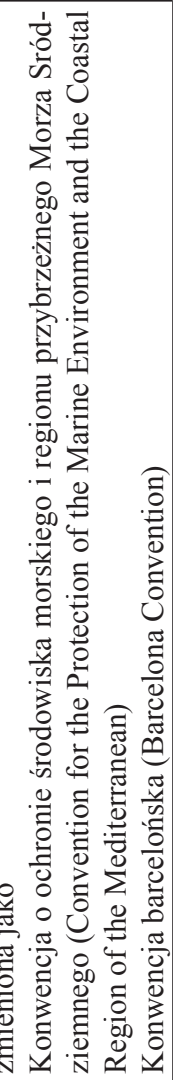 & 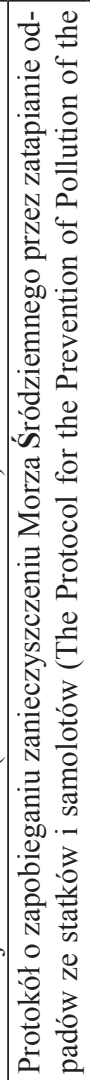 & 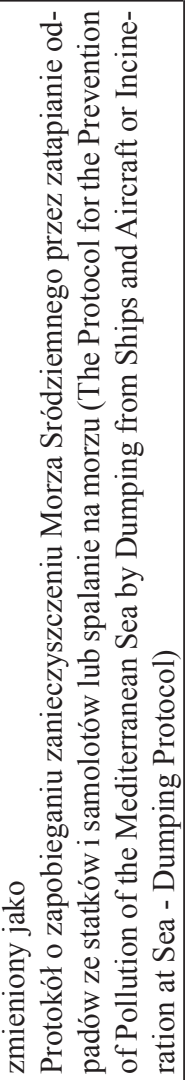 & 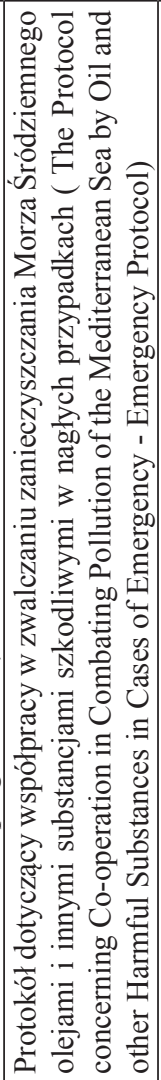 & 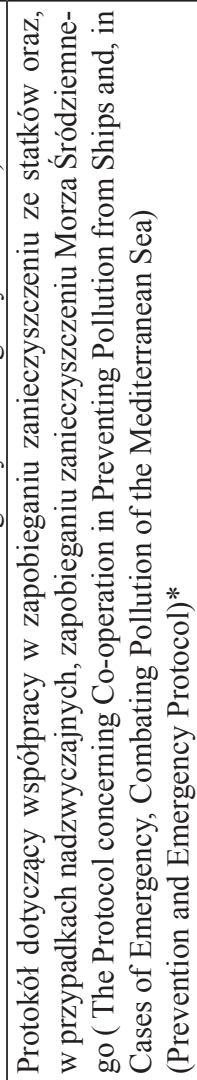 \\
\hline
\end{tabular}

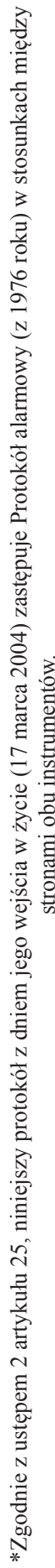




\begin{tabular}{|c|c|c|c|c|c|c|c|}
\hline 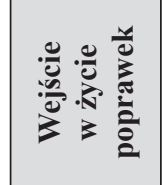 & 1 & 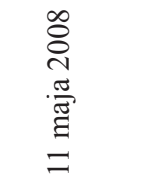 & 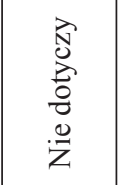 & 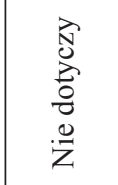 & 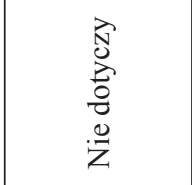 & 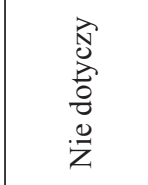 & 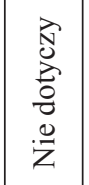 \\
\hline 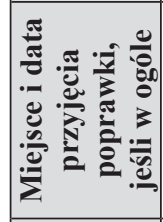 & 1 & 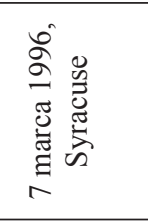 & 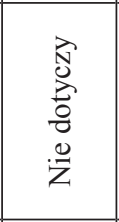 & 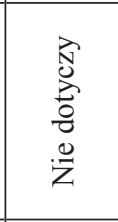 & 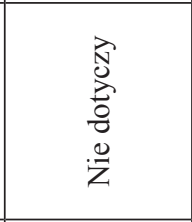 & 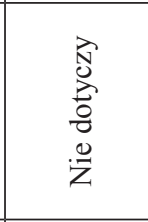 & 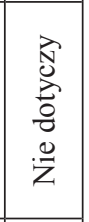 \\
\hline 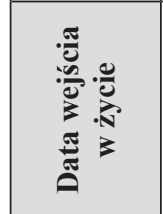 & 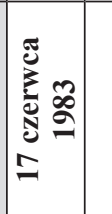 & 1 & & 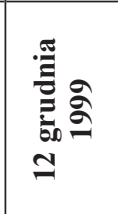 & 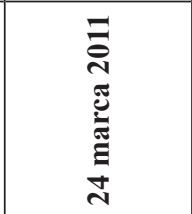 & 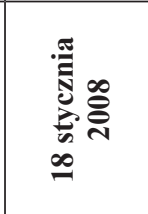 & 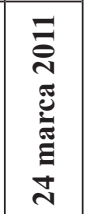 \\
\hline 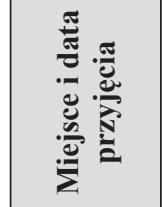 & 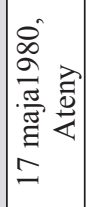 & 1 & 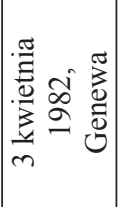 & 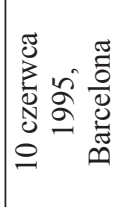 & 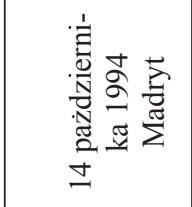 & 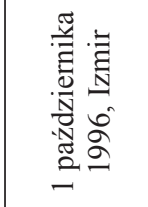 & 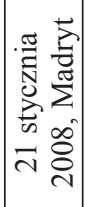 \\
\hline 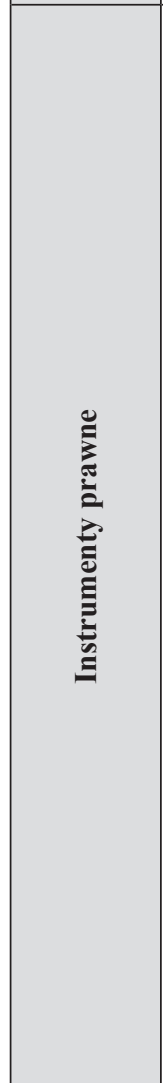 & 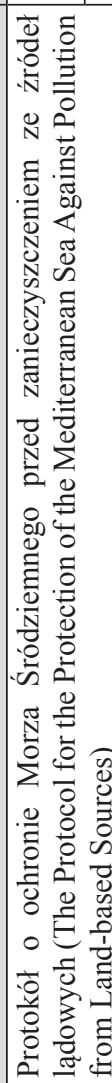 & 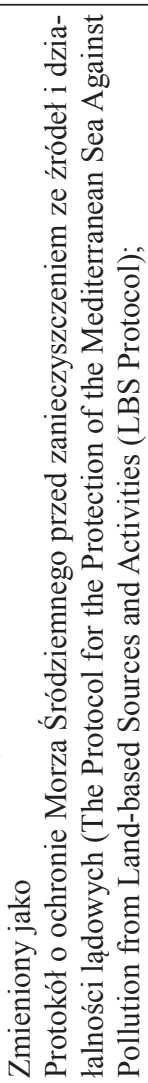 & 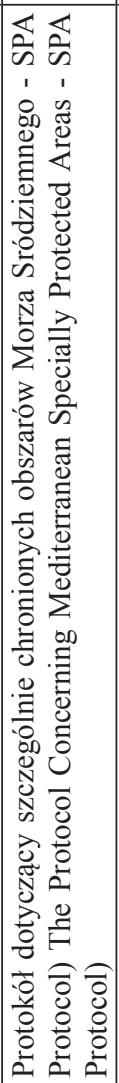 & 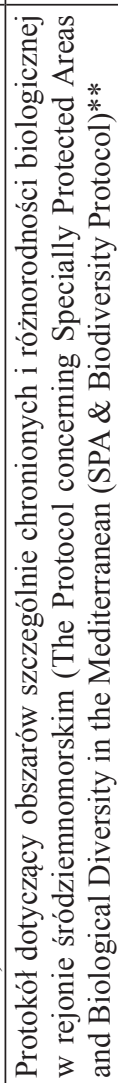 & 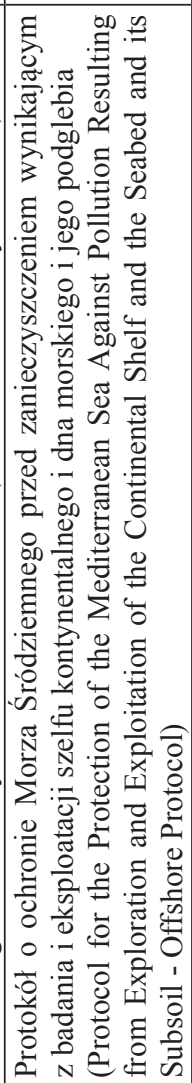 & 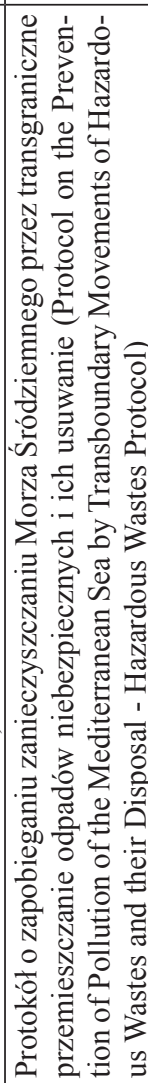 & 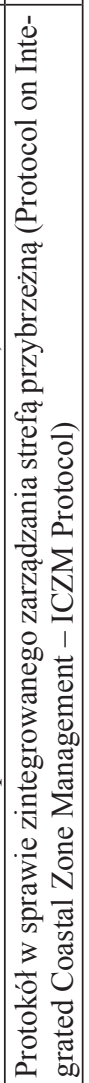 \\
\hline
\end{tabular}




\section{WYKAZ PIŚMIENNICTWA}

1. Agenda 2030 for Sustainable Development, https://sustainabledevelopment.un.org/post2015/transformingourworld/publication (20.06.2016).

2. Application de l'approche écosystémique en Méditerranée. Ensemble Pour Une Méditerranée Saine Avec Des Écosystèmes Côtiers Et Marins Productifs Et Biologiquement Diversifiés Pour Le Bénéfice Des Générations Présentes Et Futures, http://195.97.36.231/dbases/MAPpublications/ EcosystemApproach2015_Fre.pdf. (7.07.2016).

3. Approche Par Écosystème, Lignes Directrices De La CDB, https://www.cbd.int/doc/publications/ ea-text-fr.pdf, 6.

4. Barcelona Convention, http://www.unepmap.org/index.php?module $=$ content2\&catid $=001001004$ (30.06.2016).

5. Barcelona Convention for the protection of the Mediterranean, http://eur-lex.europa.eu/legal-content/FR/TXT/?uri=URISERV\%3Al28084>.(30.06.2016)

6. Baum R., Śleszyński J., 2008: Teoretyczne aspekty trwałego i zrównoważonego rozwoju gospodarstw rolnych, Ekonomia i Środowisko. 1 (33), 9.

7. Blue Growth, http://ec.europa.eu/maritimeaffairs/policy/blue_growth/index_en.htm (10.07.2016).

8. BP/RAC Blue Plan/Regional Activity Centre, http://planbleu.org/ (5.06.2016).

9. Commission mondiale sur l'environnement et le développement, Notre avenir à tous Quebec 1989, 51 .

10. Communication de la Commission au Parlament Européen, au Conseil, au Comité économique et Social Économique et Social Européen et au Comité des Régions. La croissance bleue: des possibilités de croissance durable dans les secteurs marin et maritime (Texte présentant de l'intérêt pour l'EEE): $\mathrm{COM(2012)} 494$ final, Bruxelles, le 13.9.2012. 2-15.

11. Convention de Barcelone pour la protection de la Méditerranée, http://195.97.36.231/dbases/ webdocs/BCP/bc76_fre.pdf (30.06.2016).

12. Convention sur la protection du milieu marin et du littoral de la Méditerranée, http://195.97.36.231/ dbases/webdocs/BCP/bc95_fre_p.pdf (30.06.2016).

13. Décision du Conseil, du 25 juillet 1977, portant conclusion de la convention pour la protection de la mer Méditerranée contre la pollution ainsi que du protocole relatif à la prévention de la pollution de la mer Méditerranée par les opérations d'immersion effectuées par les navires et aéronefs: 77/585/CEE, http://eur-lex.europa.eu/legal-content/FR/TXT/?uri=celex\%3A31977D0585 (3.07.2016).

14. Décision $n^{\circ} 1600 / 2002 / C E$ du Parlement européen et du Conseil du 22 juillet 2002 établissant le sixième programme d'action communautaire pour l'environnement : JO L 242 z 10.09.2002, http://eur-lex.europa.eu/legal-content/FR/TXT/?uri=celex\%3A32002D1600 (20.06.2016).

15. Dyrektywa Parlamentu Europejskiego i Rady 2014/89/UE z dnia 23 lipca 2014 r. ustanawiająca ramy planowania przestrzennego obszarów morskich: Dz. Urz. L 257, z 28.08.2014, 135, http:// eur-lex.europa.eu/legal-content/PL/TXT/?uri=CELEX\%3A32014L0089 (10.07.2016).

16. Directive 2008/56/CE du Parlement Européen et du Conseil 17 juin 2008 établissant un cadre d'action communautaire dans le domaine de la politique pour le milieu marin (directive-cadre «stratégie pour le milieu marin») (Texte présentant de l'intérêt pour l'EEE): JO L 164/19 z 25.06.2008, http://eur-lex.europa.eu/legal-content/FR/ALL/?uri=CELEX\%3A32008L0056, $19-40$.

17. Etat de l'environnement et du développement en Méditerranée: 2009, http://planbleu.org/fr/ publications/etat-de-lenvironnement-et-du-developpement-en-mediterranee-200, 21-22. 
18. État du milieu marin et côtier de méditerranée. Principaux elements destines aux décideurs politiques: 2012, UNEP/MAP, 4a, 5a.

19. Frémont A., 2008: Les relations maritimes de l'Europe en Méditerranée: ouverture sur le grand large et oubli des voisins. Strates: Union européenne - Voisinages. La quête d'une intégration régionale 15,189-208.

20. Guide de mise en œuvre de l'approche écosystémique dans le contexte de l'application de la directive-cadre stratégie pour le milieu, http://ec.europa.eu/environment/life/project/Projects/index. $\mathrm{cfm}$ ?fuseaction=home.showFile\&rep=file\&fil=PISCES_le_guide_pisces_FR.pdf, 9. (7.07.2016).

21. Hadhri M., 2006: Environnement et développement durable en Méditerranée, w: F. Praussello Sustainable Development and Adjustment in the Mediterranean Countries Following the EU Enlargement, Milano, 10.

22. Hervé V., 2011: Dégradation de l'environnement en Méditerranée: quelle action régionale http:// www.nouvelle-europe.eu/degradation-de-l-environnement-en-mediterranee-quelle-action-regionale> (18 czerwca 2016).

23. Integrated maritime policy, http://ec.europa.eu/maritimeaffairs/policy/index_en.htm (16.07.2016).

24. Komunikat Komisji Europa 2020. Strategia na rzecz inteligentnego i zrównoważonego rozwoju sprzyjającego włączeniu społecznemu: KOM(2010)2020, Bruksela 3.03.2010. http://ec.europa. eu/eu2020/pdf/1_PL_ACT_part1_v1.pdf, (15.07.2016), 21.

25. Konferencja Narodów Zjednoczonych w sprawie Zrównoważonego Rozwoju, http://www.unic. un.org.pl/rio20 (10.07.2016).

26. La gestion intégrée des activités, http://www.developpement-durable.gouv.fr/La-gestion-integree-des-zones.html (19.07.2016).

27. Mediterranean Climate change Adaptation Awards, http://www.ademe.fr/en/mediterranean-climate-change-adaptation-awards (7.07.2016).

28. Med Pol programme for the Assessment and Control of Marine Pollution in the Mediterranean, http://www.iucn.org/fr/node/12572 (10.07.2016).

29. Morskie planowanie przestrzenne, http://ec.europa.eu/maritimeaffairs/policy/maritime_spatial_ planning/index_pl.htm (15.07.2016).

30. Norgaard R. B., 2010: Ecosystem services. From eye-opening metaphor to complexity blinder, Ecological Economics. 69, 1219-1227.

31. Parrain C., 2012: La haute mer: un espace aux frontières de la recherche géographique, EchoGéo. 19, https://echogeo.revues.org/12929.(6.06.2016).

32. Poncet J.,1973: Les problème de l'environnement méditerranéen, Revue de l'Occident musulman et de la Méditerranée. 15-16, 257-267a, 165 b.

33.RAC/SPA Regional Activity Center for Specially Protected Areas, http://www.rac-spa.org/ (10.07.2016).

34. Stachurska-Szczesiak K., 2015: Water management as a challenge to sustainable development, TEKA Komisji Politologii i Stosunków Międzynarodowych 10/2, s. 85-91.

35. Stratégie Méditerranéenne pour le développement durable 2016-2025. Investir dans la durabilité environnementale pour atteindre le développement économique et social, http://planbleu.org/sites/ default/files/publications/smdd_2016-2025_final.pdf(10.07.2016), 4, 7.

36. Sustainable Developement Goals - SDGs http://www.un.org/sustainabledevelopment/sustainable-development-goals/ (10.07.2016).

37. The Convention on Biological Diversity CBD, https://www.cbd.int/convention/(18.07.2016).

38. Weigert M., 2012: Les défis du tourisme dans la région méditerranéenne, Économie et territoire. Structure productive et marché du travail http://www.iemed.org/observatorifr/areesdanalisi/arxiusadjunts/anuari/med.2012/weigert_fr.pdf, 231-235(10.07.2016). 
39. Wpływ rybołówstwa na środowisko (Polski) http://ryby.wwf.pl/przewodnik-wwf-po-rybach-i-owocach-morza/wplyw-rybolowstwa-na-srodowisko/ (20.06.2016).

\title{
ENVIRONMENTAL THREATS MEDITERRANEAN SEA CHALLENGE FOR THE SUSTAINABLE DEVELOPMENT
}

\begin{abstract}
Environment condition the socio-economic development of the coastal States of the Mediterranean (ME), which, paradoxically, are responsible for the current state of Mediterranean flora and fauna. At the beginning of the twenty-first all the research on the marine environment of the Mediterranean they were consistent in terms of steadily deteriorating health condition of Mare Nostrum. These problems are increasingly visible on the southern shores of countries Mediterranean. This fact has been neglected for many years by the developing countries of the South, which focused more on maintaining economic growth than preserving and protecting the environment. In recent times, despite the unstable situation in the region is growing awareness that the problems associated with the environment, are often cross-cutting and require solutions nestled on international cooperation, especially when it comes to a common space that is the Mediterranean Sea. The key solution for maintaining a healthy marine environment, and economic and social development Mediterranean is to implement the principles of the concept of sustainable development. This article aims to analyze the activities of the coastal States and the EU to protect the Mediterranean paving the way for the establishment of sustainable development in the Mediterranean in the future.
\end{abstract}

Key words: Environmental threats, Mediterranean Sea, sustainable development, EU action, cooperation in the Mediterranean region. 